\title{
Ecophysiology of deciduous plants grown at different densities in the semiarid region of Brazil
}

\section{Marlete Moreira de Sousa Mendes ${ }^{1 *}$, Claudivan Feitosa de Lacerda², Francisco Éden Paiva Fernandes ${ }^{3}$, Ana Clara Rodrigues Cavalcante ${ }^{3}$, Teógenes Senna de Oliveira ${ }^{4}$}

'Departamento de Biologia, Universidade Federal do Ceará, (UFC), Fortaleza, CE, Brazil.

${ }^{2}$ Departamento de Engenharia Agrícola, UFC, Fortaleza, CE, Brazil.

${ }^{3}$ Embrapa Caprinos e Ovinos, Sobral, CE, Brazil.

${ }^{4}$ Departamento de Solos, CCA, UFV, Viçosa, MG, Brazil.

*Corresponding author: mendes758@hotmail.com

Received: 26 October 2012; Accepted: 03 July 2013

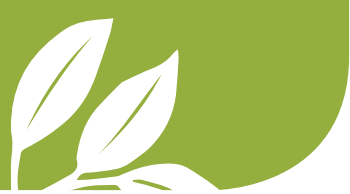

ABSTRACT: Physiological differences in the Cordia oncocalyx tree growing at different densities in two distinct areas were investigated. An agrosilvopastoral system (AGP) and a secondary forest (SF) were studied. Under both types of land-use, C. oncocalyx presented a relative frequency of approximately $50 \%$, and absolute densities of 670 and 80 individuals per hectare, respectively. Net photosynthesis $(A)$, stomatal conductance $\left(g_{\mathrm{s}}\right)$, and transpiration $(E)$ were measured, and the SPAD index was recorded in sun leaves from the canopy and shade leaves from the lower canopy, in both the wet and dry seasons. We quantified the dry biomass of leaves and fruit on a per-tree basis at the end of the wet season. Net photosynthesis was higher in shaded leaves in the AGP in the wet season, reaching an average of $4.8 \mu \mathrm{mol} \mathrm{m}^{-2} \mathrm{~s}^{-1}$ against $3.2 \mu \mathrm{mol} \mathrm{m} \mathrm{m}^{-2} \mathrm{~s}^{-1}$ under SF. As trees began to shed their leaves at the beginning of the dry season and more radiation reached the shaded leaves, there was an increase in SF for $A$, depending on the intensity of light reaching the leaves. In the sun leaves, gas exchange was similar for the land-use systems during the wet season, but stronger in AGP than under SF during the dry season. This happened when the leaves in AGP retained more relative water content during a period of low gravimetric levels of the soil water. The lower tree density in AGP promoted a higher SPAD index and dry biomass in both the sun and shaded leaves, and allowed greater $A, E$ and $g_{s}$ rates in the sun leaves at the beginning of the dry period.

KEYWORDS: agroforestry system, chlorophyll, Cordia oncocalyx, dry biomass, leaf gas exchange, secondary forest.

\section{INTRODUCTION}

With the growing world population, the demand for new areas for agriculture or livestock is also increasing, leading to more deforestation. In the face of the non-sustainability of conventional and traditional farming methods, alternative management regimes have been proposed, among which are agroforestry systems such as the silvopastoral, the silvicultural and the agrosilvopastoral systems. The agrosilvopastoral system proposes the combination of trees with agriculture and livestock.

In Brazil, studies about agroforest have been carried out mainly in the Amazon and the Atlantic Forest region, focusing on plantations of cupuaçu and pupunha (Alfaia et al. 2004), cocoa (Moço et al. 2010) and coffee (Souza et al. 2012). In the semiarid region of Brazil, studies have focused on the cultivation of maize and pasture, investigating aspects such as water and nutrient loss (Aguiar et al. 2010), physical quality of the soil (Silva et al. 2011), floristics and phytosociology (Campanha et al. 2011), nutrient dynamics, and microclimate (Menezes et al. 2002, Maia et al. 2008). However, there is no information as to the ecophysiology of plants.

In northeastern Brazil, where the Caatinga vegetation (the Brazilian woody savanna) predominates, rain distribution is irregular and temperatures are high. Traditional agriculture is therefore limited to the short wet season, usually employing slash-and-burn techniques followed by land 
cultivation and, finally, abandonment of the area (IBGE 2006). In this region, the establishment of agroforestry systems can allow the preservation of trees and the physical characteristics of the environment, together with the breeding of animals and/or production of plants.

Studies that consider the effect of reduced tree density while assessing physiological alterations in native trees or cultivated plants in agroforestry are scarce, and little is known about this topic. It is possible that tree height and biomass be negatively affected by the implementation of agroforestry systems (Lott et al. 2000, Singh et al. 2007). On the other hand, Will et al. (2001) did not observe any effect of plant density on leaf respiration or net photosynthesis. Therefore, it is important to understand how reduced plant density under an agroforestry system may influence the physiological processes of trees, which will ultimately impact on the productivity of the trees and of the system as a whole.

Based on observations made in experimental areas of Sobral, Ceará, in northeastern Brazil, it was noted that trees in secondary forests begin to shed their leaves earlier than those found in agrosilvopastoral systems. It was hypothesized that under land-use systems where tree density is lower, such as agrosilvopastoral systems, leaf gas exchange and tree biomass are higher in comparison to those of the forest. Cordia oncocalyx is a common native tree, widely distributed across the semiarid region of Brazil (Carvalho 2008). Those physiological variations were investigated, which occur in C. oncocalyx growing both under an agrosilvopastoral system and in the secondary forest, and which could justify the choice of agroforestry as a cropping system in other semiarid regions.

\section{MATERIAL AND METHODS}

Study areas: The study areas are located in the Crioula Farm, at the National Goat and Sheep Research Center, which belongs to EMBRAPA in Sobral, Ceará, northeastern Brazil (Figure 1). The location is in the semiarid region of Ceará $\left(3^{\circ} 41^{\prime} \mathrm{S}\right.$ and $\left.40^{\circ} 20^{\prime} \mathrm{W}\right)$, at a $70 \mathrm{~m}$ height, with a slope of 3 to $20 \%$. The average annual temperature is $30^{\circ} \mathrm{C}$, and the average annual rainfall is $821 \mathrm{~mm}$, with rains concentrated between February and May. The soils are Orthic Chromic Luvisol and the typical Orthic Hypochromic Luvisol (Aguiar et al. 2006). Rainfall during the study is presented in Figure 2. The prevalent vegetation in the area is the woody savanna (locally known as Caatinga) (Woodward et al. 2004) consisting mostly of deciduous species that lose their leaves during the dry season, which is from June to January.

In 1997, a long-term experiment was established by EMBRAPA to evaluate agroforestry as an alternative to traditional and conventional agricultural systems in the region.

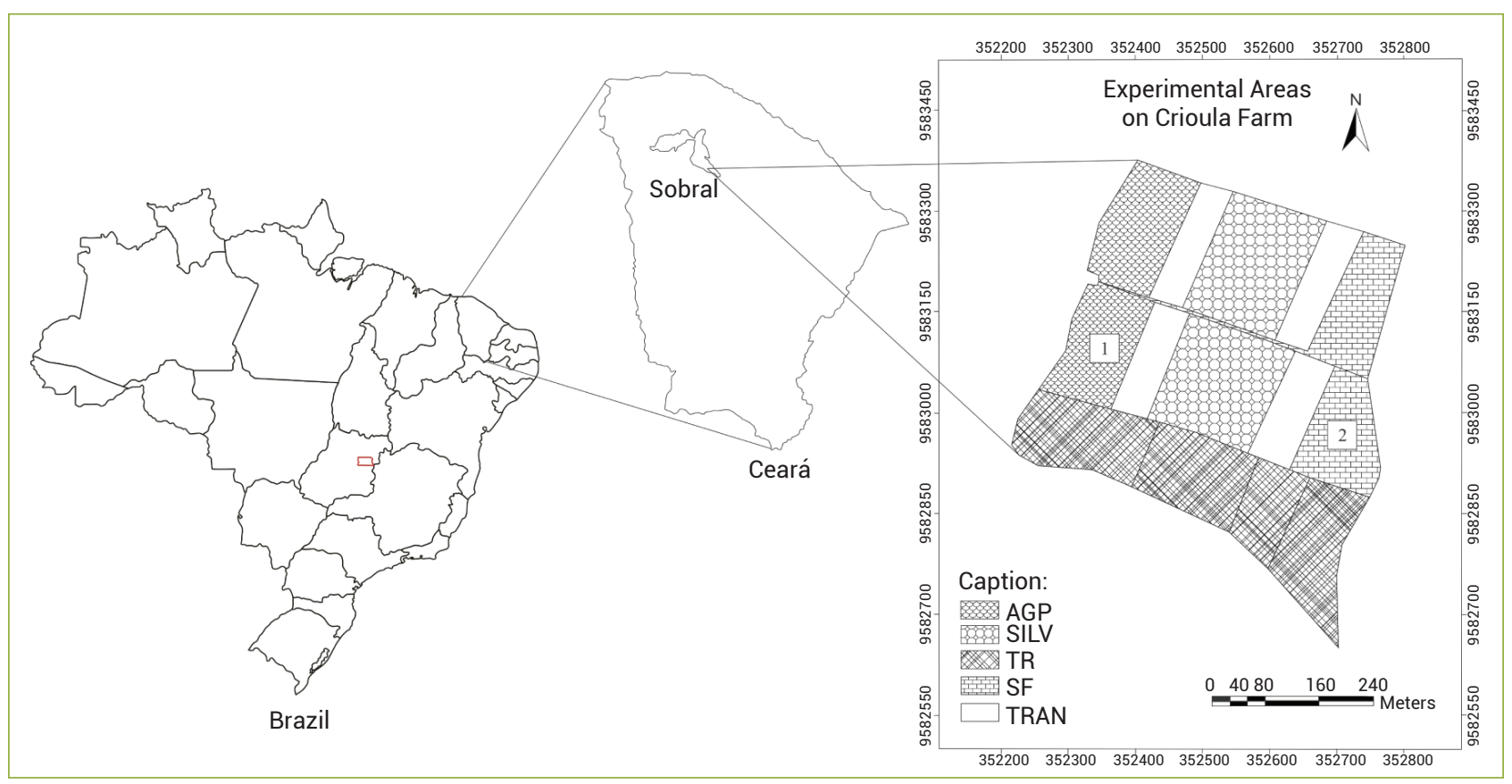

Figure 1. Map showing the experimental areas of the National Goat and Sheep Research Centre belonging to EMBRAPA, in the Crioula Farm, Sobral, Ceará, Brazil. AGP - agrosilvopastoral system, SILV - silvopastoral system, TR - traditional cropping, SF - secondary forest and TRAN - transition zones. Numbers (1 and 2) correspond to study areas used in this experiment. Source: adapted from Campanha et al. (2009). 
The systems evaluated in the experiment included: traditional cropping, agrosilvopastoral and silvopastoral, with a secondary forest used as control. Two of these systems were selected for the present study. The agrosilvopastoral system (AGP) corresponds to an area of 1.6 ha of Caatinga, where maize (Zea mays L.) or sorghum (Sorghum bicolor L. Moench) are cultivated in $3 \mathrm{~m}$ wide alleys separated by rows of leucaena [Leucaena leucocephala (Lam.) de Wit]. Some trees were removed when the system was established, leaving approximately 200 trees per hectare, corresponding to $22 \%$ of the ground cover. No fertilizers were used and crop and tree management was carried out exclusively by hand. The secondary forest (SF) corresponds to an area of 1.6 ha of Caatinga, with secondary vegetation that is approximately 50 years old covering $90 \%$ of the ground.

The areas are separated by a $800 \mathrm{~m}$ distance, and both are the same age. All the trees in the area were tillered before the experiment began because wood had been removed by the local population. However, for a long time (about 50 years), no wood had been removed from the area. In 1997, when the experiment was set up, the trees in AGP were pruned to leave only the trunk with the largest diameter. As a consequence of these managements, in SF the trees continue tillered, with the diameter of individual shoots between 0.05 and $0.11 \mathrm{~m}$, and the total for all shoots in individual trees varying between 0.25 and $0.28 \mathrm{~m}$. In 2011, the trunks in AGP presented an average diameter, at breast height, of $0.30 \mathrm{~m}$.

Plant Species Studied: Nine tree species are found in the two areas, four being common to both: Cordia oncocalyx Allemão, Mimosa caesalpiniifolia Benth., Poincianella bracteosa

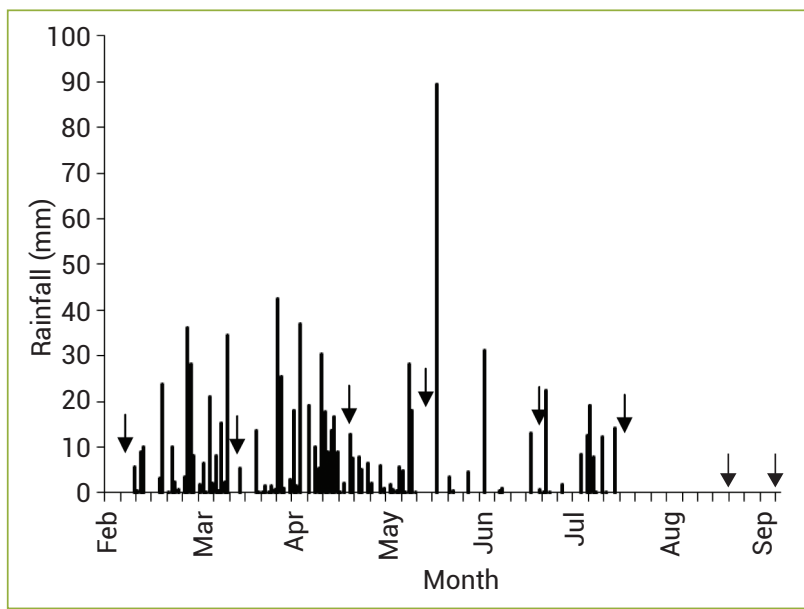

Figure 2. Daily rainfall obtained from automatic meteorological stations installed in both experimental areas (AGP and SF), from February to September, 2011. Arrows indicate days when physiological data were measured.
(Tul.) L.P. Queiroz, and Bauhinia cheilantha (Bong.) Steud. (Campanha et al. 2011). Cordia oncocalyx Allemão (locally known as pau-branco), a member of the Boraginaceae, is abundant, presenting 670 individuals per hectare in SF and 80 individuals per hectare in AGP. This species was chosen due to its high frequency of $49.1 \%$ under SF and 50\% in AGP (Campanha et al. 2008), and because it presents complete leaf abscission at different periods in the two study areas. The analyzed trees were on average $8.2 \pm 0.3 \mathrm{~m}$ high in AGP, and $9.0 \pm 0.5 \mathrm{~m}$ high under $\mathrm{SF}$, producing leaves and flowering at the beginning of the wet season (between January and February). Fruiting follows in March, and the fruits remain on the trees until the dry season starts (July or August), when the plants also begin to shed their leaves.

Water content of the soil and plants: To measure the gravimetric water content of the soil, in April (wet season) and September (dry season) three samples were collected at depths of $0-0.10,0.10-0.20,0.20-0.40$, and $0.40-0.60 \mathrm{~m}$, following the procedure outlined by EMBRAPA (1997). In order to measure the water content of the leaves, five samples of branches that had been exposed to the sun were collected from each system of land use, at a height of approximately $8 \mathrm{~m}$, from February to September, after photosynthetic rates had been measured. All the material was weighed immediately after collection to avoid water loss. The soil and plant samples were dried in an oven at $65^{\circ} \mathrm{C}$ for the leaves and at $105^{\circ} \mathrm{C}$ for the soil, for $24 \mathrm{~h}$, and then weighed again to obtain the dry weight. With these data, the percentage of water in the leaves and soil was calculated.

Physiological measurements: Physiological data from the wet season (February to July) were grouped together and separated from the data obtained during the dry season (in August and September). These sampling dates refer to 30 and 50 days after the final rainfall, respectively. June and July were considered as rainy months because 2011 was atypically wet, with a total volume of precipitation higher than the historical mean: the wet season beginning in the second half of December, 2010, and ending mid-July, 2011 (Figure 2).

Net photosynthesis $(A)$, stomatal conductance $\left(g_{s}\right)$, transpiration $(E)$, leaf-to-air vapor pressure deficit $\left(\mathrm{VPD}_{\text {leafto-iri }}\right)$, leaf temperature $\left(\mathrm{T}_{\text {leaf }}\right)$, and photosynthetically active radiation reaching the leaf when $A$ was measured (PAR), were recorded with an infrared gas analyzer (LI-6400XT, LI-COR Biosciences, USA) under conditions of natural temperature, $\mathrm{CO}_{2}$ and light. Water use efficiency (WUE) was calculated as the ratio between $A$ and $E$.

Three sun canopy leaves and shaded leaves from the lower canopy, from three trees per system, were used for 
measurements. To reach the sun leaves, three scaffolding towers were assembled in each system, one per each tree, with a height similar to that of the plants, between eight and nine meters.

Measurements were taken from shaded and sun leaves one day a month, from February to September, between noon and $1: 00 \mathrm{pm}$. In order to assess the daily cycle of gas exchange in sun leaves, measurements taken at 7-8:00 am, 10-11:00 am and 3-4:00 am between May and September were added to the data.

The SPAD index of the leaves was measured with a portable device (SPAD-502P, Minolta, Japan) that detects the intensity of the green color of the leaf. Data consisted of the average of three measurements per leaf, three leaves per tree, three trees from both the AGP and SF, and included sun and shaded leaves.

Leaf and fruit biomass: At the end of the wet season, before the beginning of leaf abscission, all the leaves from three trees in each system were collected and weighed. These trees had similar characteristics in relation to those chosen for leaf gas exchange measurements. Sun leaves, shaded leaves and fruits were separated. Three subsamples of leaves and three subsamples of fruits from each tree were then taken and dried to constant weight in an oven at $65^{\circ} \mathrm{C}$ in order to measure dry mass. These data were used to calculate the percentage of dry biomass (PDM \%) as (DMs x 100)/FMs, in which DMs is the dry biomass of the subsample and FMs is the fresh biomass of the subsample, both in grams. To calculate the total dry biomass of the sample (TDM, in $\mathrm{kg} \mathrm{tree}^{-1}$ ), the values of the total fresh biomass samples per tree (TFM, in $\mathrm{kg}$ tree $^{-1}$ ) were multiplied by the PDM.

Statistical analysis: Variance analysis was carried out followed by the Tukey's test $(a=5 \%)$ to evaluate the differences between seasons (wet season, 30 and 50 days after the final rainfall) and land-use systems (AGP and SF) in $\mathrm{T}_{\text {leaf }}, \mathrm{VPD}_{\text {leaf-to-air }}, \mathrm{PAR}$, gas exchange and water use efficiency in shaded leaves, as well as SPAD index in sun and shaded leaves. Data of the soil gravimetric moisture, leaf water content, gas exchange and water use efficiency in sun leaves, $\mathrm{VPD}_{\text {leaf-to-air, }}$ at different times of the day, and the dry biomass of sun and shaded leaves, were analyzed with the Student's $t$-test. The BioEstat 5.0 software (Ayres et al. 2007) was used to carry out statistical analyses, and figures were prepared using the Microcal Origin ${ }^{\mathrm{TM}}$ (1997) software.

\section{RESULTS}

Water content of soil and plants: The soil gravimetric moisture content in April varied between 16 and 22\% in
AGP and between 19 and $25 \%$ in SF. It differed significantly between systems only in the $0-0.1 \mathrm{~m}$ depth range, with greater moisture in AGP (Figure 3A). During the dry season, in September, percentages varied between 5 and $7 \%$ in AGP and 6 and $8 \%$ in SF, and moisture content was lower in AGP at all other evaluated depths (Figure $3 \mathrm{~B}$ ). In both study areas, the moisture content of the leaves varied from 60 to $70 \%$ between February and June, and from 50 to $60 \%$ starting from July. Leaf water content tended to be lower in AGP, but no significant differences were observed for most months. In September, 50 $\mathrm{d}$ after the final rainfall, the trend was reversed, with greater leaf water content in AGP than in SF (Figure 4).

\section{Leaf temperature, photosynthetically active} radiation and vapor pressure deficit: The temperature $\left(\mathrm{T}_{\text {leaf }}\right)$ of the sun leaves was higher in SF than in AGP during the dry season, both on the $30^{\text {th }}$ and $50^{\text {th }} \mathrm{d}$ after the final rainfall. In contrast, the temperature of the shaded leaves

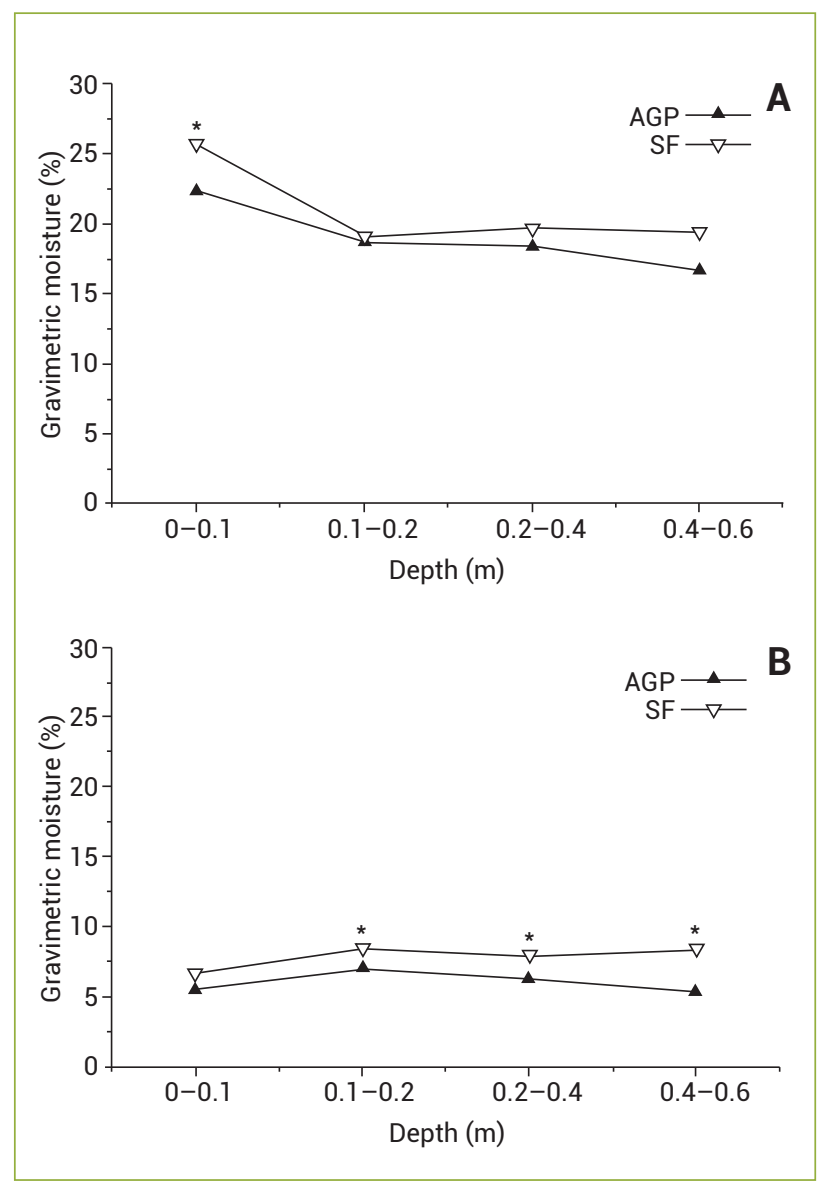

Figure 3. Gravimetric soil moisture in April (A) and September (B), at four depth increments, in an agrosilvopastoral system (AGP) and a secondary forest $(\mathrm{SF})(\mathrm{n}=3)$. *indicates statistically significant differences between land-use systems, by Student's $t$-test $(p<0.05)$. 
differed between the systems only $50 \mathrm{~d}$ after the final rainfall (Table 1). In the sun leaves, $\mathrm{T}_{\text {leaf }}$ increased $3.7^{\circ} \mathrm{C}$ in AGP and $6.4^{\circ} \mathrm{C}$ in SF between the wet season and 50 days after the final rainfall. In the shaded leaves, the increased $\mathrm{T}_{\text {leaf }}$ during the same period amounted to $7.2^{\circ} \mathrm{C}$ in AGP and $9.5^{\circ} \mathrm{C}$ in SF. The photosynthetically active radiation (PAR) reaching the sun leaves differed between systems in the rainy period and $30 \mathrm{~d}$ after the final rainfall, but it was the same in both systems 50 $\mathrm{d}$ after the final rainfall. The PAR reaching the shaded leaves in SF was 20 times higher $50 \mathrm{~d}$ after the final rainfall as compared to the wet season, but PAR reaching the shaded leaves in AGP did not differ significantly in these two dates (Table 1). We recorded strong variations in $\mathrm{VPD}_{\text {leaf-to-air }}$ between the rainy and dry seasons, in both shaded and sun leaves and in both

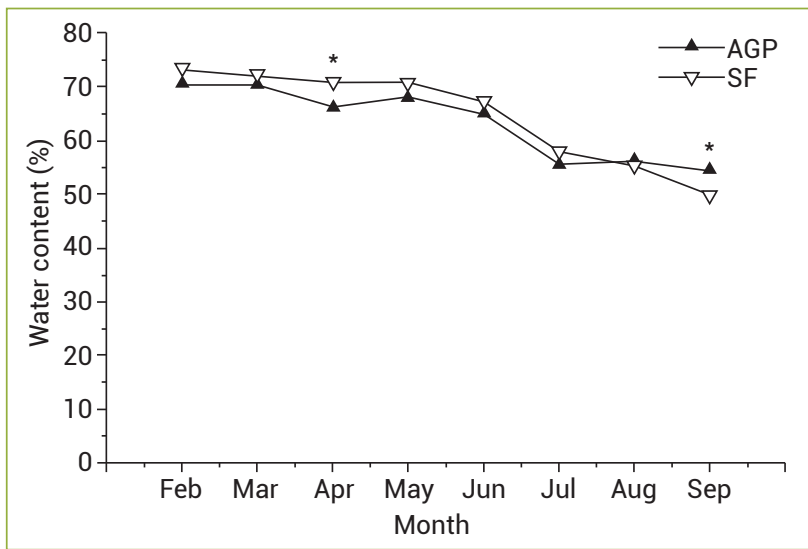

Figure 4. Water content in sun leaves of Cordia oncocalyx in an agrosilvopastoral system (AGP) and a secondary forest (SF) $(n=5)$. *indicates statistically significant differences between land-use systems, by Student's $t$-test $(p<0.05)$. land-use systems. An increase in $\mathrm{VPD}_{\text {leaf-to-air }}$ of more than $50 \%$ was observed in the sun leaves in AGP, as well as an increase of more than $100 \%$ in the sun leaves in SF. Fifty $d$ after the final rainfall, $\mathrm{VPD}_{\text {leaf-to-air }}$ was higher in SF than in AGP for both sun and shaded leaves, with a $1.6 \mathrm{kPa}$ increase in the sun leaves and $0.84 \mathrm{kPa}$ in the shaded leaves (Table 1).

Gas exchange and water use efficiency in shade leaves: In the wet season, shaded leaves of $C$. oncocalyx presented higher $A$ rates in AGP (on average $4.8 \mu \mathrm{mol} \mathrm{m}^{-2} \mathrm{~s}^{-1}$ ) than in SF (on average $3.2 \mu \mathrm{mol} \mathrm{m}^{-2} \mathrm{~s}^{-1}$ ). Starting in August, this trend was reversed, and $50 \mathrm{~d}$ after the final rainfall, the leaves in SF exhibited higher $A$ rates than in AGP (on average 1.23 and $0.80 \mu \mathrm{mol} \mathrm{m} \mathrm{m}^{-2} \mathrm{~s}^{-1}$, respectively, Figure 5A). Conversely, in the dry season, $g_{s}$ was higher on average in AGP ( 0.05 and $0.03 \mathrm{~mol} \mathrm{~m}^{-2} \mathrm{~s}^{-1}$ at 30 and $50 \mathrm{~d}$, respectively) than in SF (0.03 and $0.02 \mathrm{~mol}$ $\mathrm{m}^{-2} \mathrm{~s}^{-1}$ at 30 and $50 \mathrm{~d}$, respectively). The same occurred with $E$, which was greater in AGP $\left(2.5\right.$ and $2.0 \mathrm{mmol} \mathrm{m}^{-2} \mathrm{~s}^{-1}$ at 30 and 50 days, respectively) than in SF $\left(1.7 \mathrm{mmol} \mathrm{m}^{-2} \mathrm{~s}^{-1}\right.$ at 30 and $50 \mathrm{~d}$ ). This led to lower WUE in plants of this system 30 and $50 \mathrm{~d}$ after the final rainfall (Figure 5B-D).

\section{Gas exchange and water use efficiency in sun leaves:}

Gas exchange was more intense during the wet season and in the morning, decreasing from midday on. Net photosynthesis was similar between systems in the wet season at all times, with averages ranging from 6 (in the afternoon) to $10 \mu \mathrm{mol} \mathrm{m} \mathrm{m}^{-2} \mathrm{~s}^{-1}$ (in the morning and at midday). However, starting $30 \mathrm{~d}$ after the final rainfall, $\mathrm{CO}_{2}$ assimilation was higher in plants in AGP for the entire day, the difference being highest $50 \mathrm{~d}$ after the final rainfall (Figure 6A).

Table 1. Leaf temperature $\left(T_{\text {leaf }}\right)$, photosynthetically active radiation (PAR), and leaf-to-air vapor pressure deficit $\left(V_{P D} D_{\text {leaf-to-air }}\right)$ of sun and shaded leaves of Cordia oncocalyx measured between noon and 1:00 pm in an agrosilvopastoral system (AGP) and a secondary forest (SF), in the wet season, 30 and 50 days after final rainfall

\begin{tabular}{|c|c|c|c|c|c|c|}
\hline \multirow{2}{*}{ Season } & \multicolumn{2}{|c|}{$\mathrm{T}_{\text {leaf }}\left({ }^{\circ} \mathrm{C}\right)$} & \multicolumn{2}{|c|}{ PAR $\left(\mu \mathrm{mol} \mathrm{m} \mathrm{m}^{-2} \mathrm{~s}^{-1}\right)$} & \multicolumn{2}{|c|}{$V P D_{\text {(leaf-to-air) }}(\mathrm{kPa})$} \\
\hline & AGP & SF & AGP & SF & AGP & SF \\
\hline \multicolumn{7}{|l|}{ Sun leaves } \\
\hline Wet season & 34.17 & 35.01 & $1,795.83$ & $1,373.37$ & 2.71 & 2.73 \\
\hline 30 days & 37.26 & 39.45 & $2,064.87$ & $1,508.89$ & 4.40 & 3.56 \\
\hline 50 days & 37.87 & 41.39 & $1,901.47$ & $1,628.24$ & 4.69 & 6.29 \\
\hline \multicolumn{7}{|l|}{ Shaded leaves } \\
\hline Wet season & 32.74 & 32.28 & 62.09 & 38.52 & 2.61 & 2.46 \\
\hline 30 days & 38.59 & 39.34 & 69.92 & 189.02 & 5.14 & 5.64 \\
\hline 50 days & 39.90 & 41.83 & 109.91 & 863.65 & 5.86 & 6.70 \\
\hline
\end{tabular}

Wet season data represents averages of the values obtained between February and July ( $n=54) ; 30$ day data represents averages of the values obtained in August, 30 days after the final rainfall and into the dry season $(n=9) ; 50$ day data represents averages of the values obtained in September, 50 days after the final rainfall and into the dry season $(n=9)$. Different lowercase letters indicate significant differences $(p<0.05)$ between seasons within the same land-use system, and different uppercase letters indicate significant differences $(\mathrm{p}<0.05)$ between land-use systems (Tukey's test). 
Stomatal conductance and $E$ differed between systems in the wet season, and were higher for leaves in SF, with $g_{s}$ being higher starting from midday, and $E$ starting from 9:00 am. However, in the dry season these parameters were greater in AGP for all of the observed times (Figure 6B-C). The $g_{\text {s }}$ decreased in the afternoon 30 and 50 days after the final rainfall (Figure 6B). It reached its lowest values at 3-4:00 pm, namely 0.09 and $0.05 \mathrm{~mol} \mathrm{~m}^{-2} \mathrm{~s}^{-1}$ in AGP and SF, respectively, at $30 \mathrm{~d}$, and 0.05 and $0.04 \mathrm{~mol} \mathrm{~m}^{-2} \mathrm{~s}^{-1}$ in AGP and SF, respectively, at $50 \mathrm{~d}$. However, despite the reduction in $g_{s}$ at 3-4:00 pm, in the leaves in AGP $50 \mathrm{~d}$ after the final rainfall $E$ remained high with values similar to those recorded $30 \mathrm{~d}$ after the final rainfall (3.05 and $3.27 \mathrm{mmol} \mathrm{m}^{-2} \mathrm{~s}^{-1}$, respectively). There was a slight $E$ reduction in trees in SF at 3-4:00 pm between 30 and $50 \mathrm{~d}$ after the final rainfall (2.31 and $1.66 \mathrm{mmol} \mathrm{m}^{-2} \mathrm{~s}^{-1}$, respectively) (Figure 6C).

Water use efficiency in the wet season decreased from 9:00 am on (Figure 6D). Consequently, systems started to differ from one another, and plants in AGP exhibited higher WUE between noon and 1:00 pm and 3-4:00 pm. Thirty days after the final rainfall, WUE was more similar between systems, but it was still higher in AGP from 7-8:00 am to noon-1:00 pm when it reached averages of 2.07 and $1.28 \mu \mathrm{mol} \mathrm{mmol}{ }^{-1}$. The greatest difference occurred $50 \mathrm{~d}$ after the final rainfall, when the highest averages for all times were recorded in trees in AGP (between $2.55 \mu \mathrm{mol} \mathrm{mmol}^{-1}$ at 7-8:00 am and $0.87 \mu \mathrm{mol} \mathrm{mmol}^{-1} 3-4: 00 \mathrm{pm}$ ).

During the wet period, the leaf-to-air VPD differed only at 3:00 pm (Figure 7A). Unlike $g_{s}$ and $A$, the daily trend in $\mathrm{VPD}_{\text {leaf-to-air }}$ showed a progressive increase in the dry season after the early hours of the day in both systems. At midday and at 3-4:00 pm, the greatest values of $\mathrm{VPD}_{\text {leaf-to-air }}$ were recorded for all periods. Thirty days after the final rainfall, $\mathrm{VPD}_{\text {leaf-to-air }}$ was different between AGP and SF for all observed times, however, it was higher in AGP (5.84 kPa) than in $\mathrm{SF}$ $(5.28 \mathrm{kPa})$ at $3-4: 00 \mathrm{pm}$ (Figure $7 \mathrm{~B})$. Fifty days after the

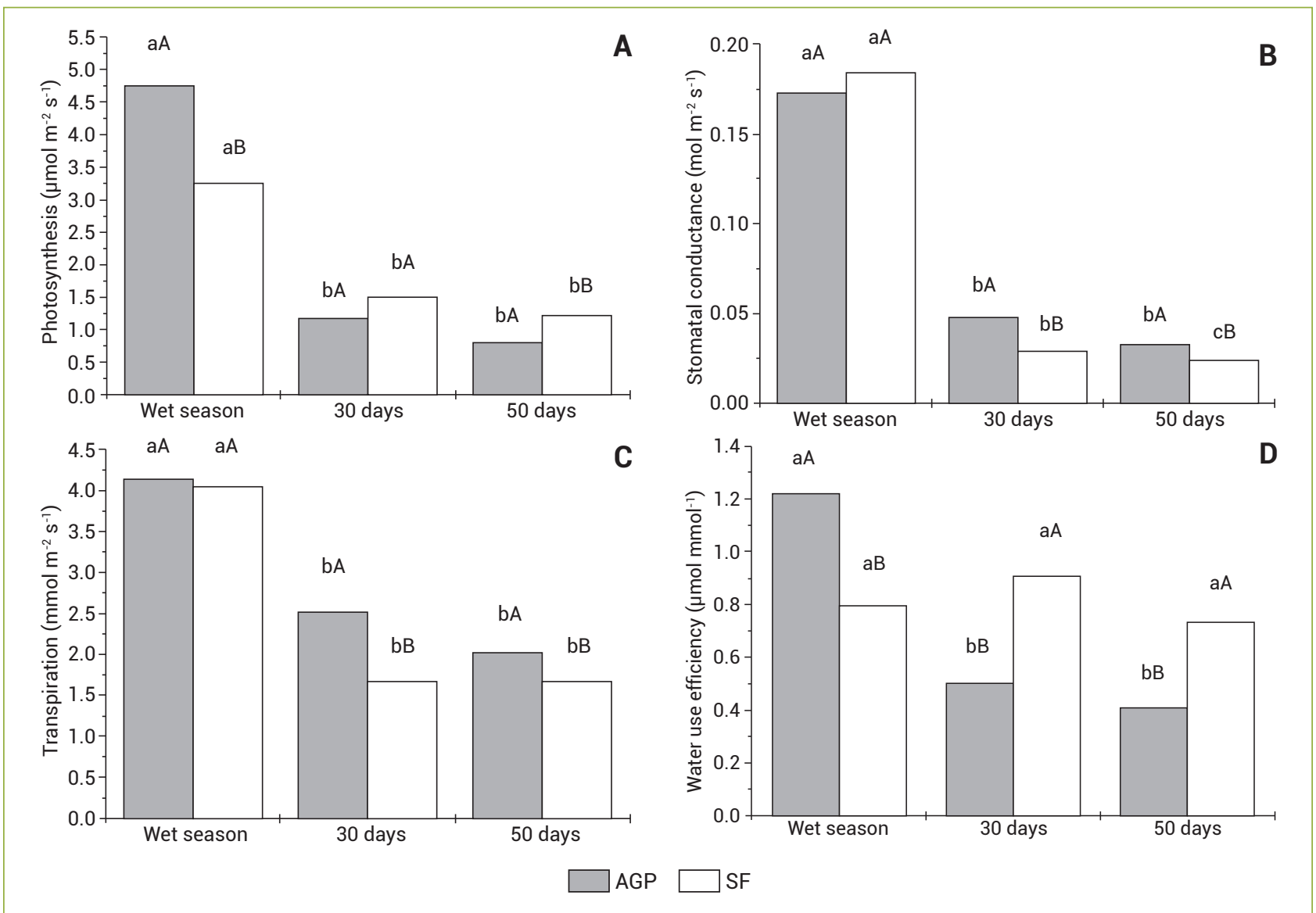

Figure 5. Net photosynthesis (A), transpiration (B), stomatal conductance (C), and water use efficiency (D) in shaded leaves of Cordia oncocalyx in an agrosilvopastoral system (AGP) and a secondary forest (SF). Wet season data represent averages of the values obtained between February and July $(n=54) ; 30$ days data represents averages of the values obtained in August, 30 days after the final rainfall and into the dry season $(n=9) ; 50$ days data represents averages of the values obtained in September, 50 days after the final rainfall and into the dry season $(n=9)$. Different lowercase letters indicate significant differences $(p<0.05)$ between seasons within the same land-use system, and different uppercase letters indicate significant differences $(p<0.05)$ between land-use systems (Tukey's test). 
final rainfall, $\mathrm{VPD}_{\text {leaf-to-air }}$ was generally higher in trees of SF. Furthermore, at 3-4:00 pm, $\mathrm{VPD}_{\text {leaf-to-air }}$ was the same $(5.7 \mathrm{kPa})$ in trees of both AGP and SF (Figure 7C).

Chlorophyll: The SPAD index of the shaded leaves was higher in AGP for all measurements (Figure 8A). In SF, the SPAD index was different for the wet season and $50 \mathrm{~d}$ after the final rainfall (34.9 and 29.5, respectively), with a reduction during this period also observed in AGP, showing averages of 50.6 and 48.4, respectively. The SPAD index in sun leaves differed between systems in the wet season and $50 \mathrm{~d}$ after the final rainfall, with the highest values occurring in AGP (44.9 and 40.4, respectively) (Figure $8 B$ ). The SPAD index of the sun leaves in AGP did not change in the wet and dry seasons, while in SF they were reduced for the period between 30 and $50 \mathrm{~d}$ after the final rainfall.

Dry biomass of Cordia oncocalyx: We recorded the highest production of total fresh biomass in the leaves and fruits in AGP, with almost three times more fresh biomass per tree in AGP than in SF. The percentage of dry biomass in the fruits and shaded leaves was also higher under this system, reaching almost $80 \%$ for fruits and $40 \%$ for leaves. The total average dry biomass (when combining fruits and leaves) per plant was $4.0 \mathrm{~kg} \mathrm{tree}^{-1}$ in $\mathrm{SF}$ and $20 \mathrm{~kg}$ tree $^{-1}$ in AGP (Table 2). In both AGP and SF, shaded leaves contributed a little to the total dry biomass per tree (13.2 and 14.8\%, respectively). Fruits of trees in AGP
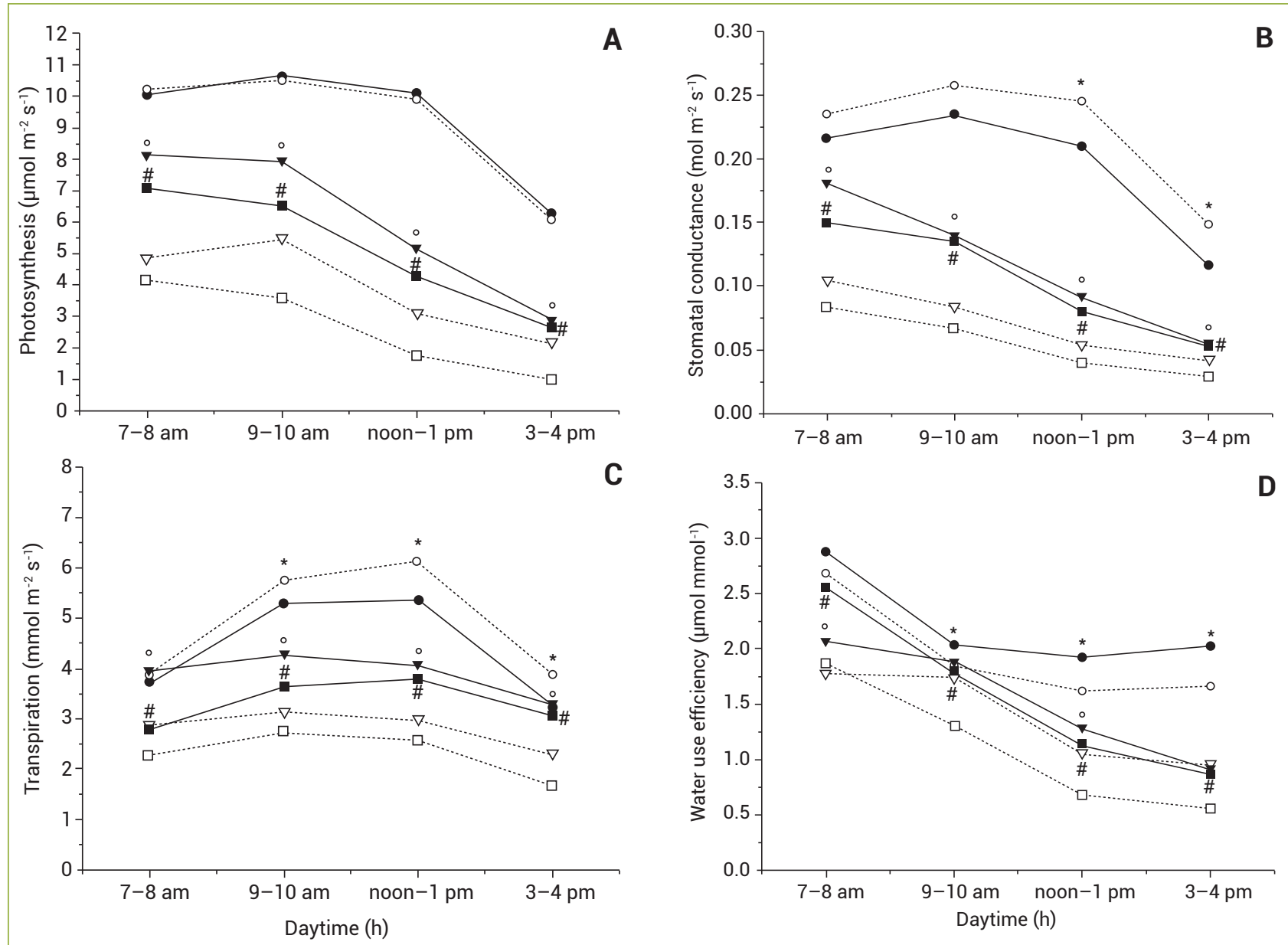

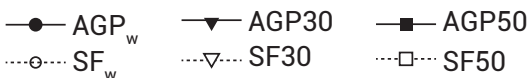

Figure 6. Net photosynthesis (A), stomatal conductance (B), transpiration (C) and water use efficiency (D) in sun leaves of Cordia oncocalyx, in an agrosilvopastoral system (AGP) and a secondary forest (SF). AGPw and SFw = wet season, averages of the values obtained between February and July $(n=54) ; A G P 30$ and SF30 = averages of the values obtained in August, 30 days after the final rainfall and into the dry season ( $n=9$ ); $A G P 50$ and SF50 = averages of the values obtained in September, 50 days after the final rainfall and into the dry season $(n=9)$. Symbols indicate significant differences ( $p<0.05$ ) between systems: * between AGPw and SFw; ${ }^{\circ}$ between AGP30 and SF30; \# between AGP50 and SF50, by Tukey's test. 


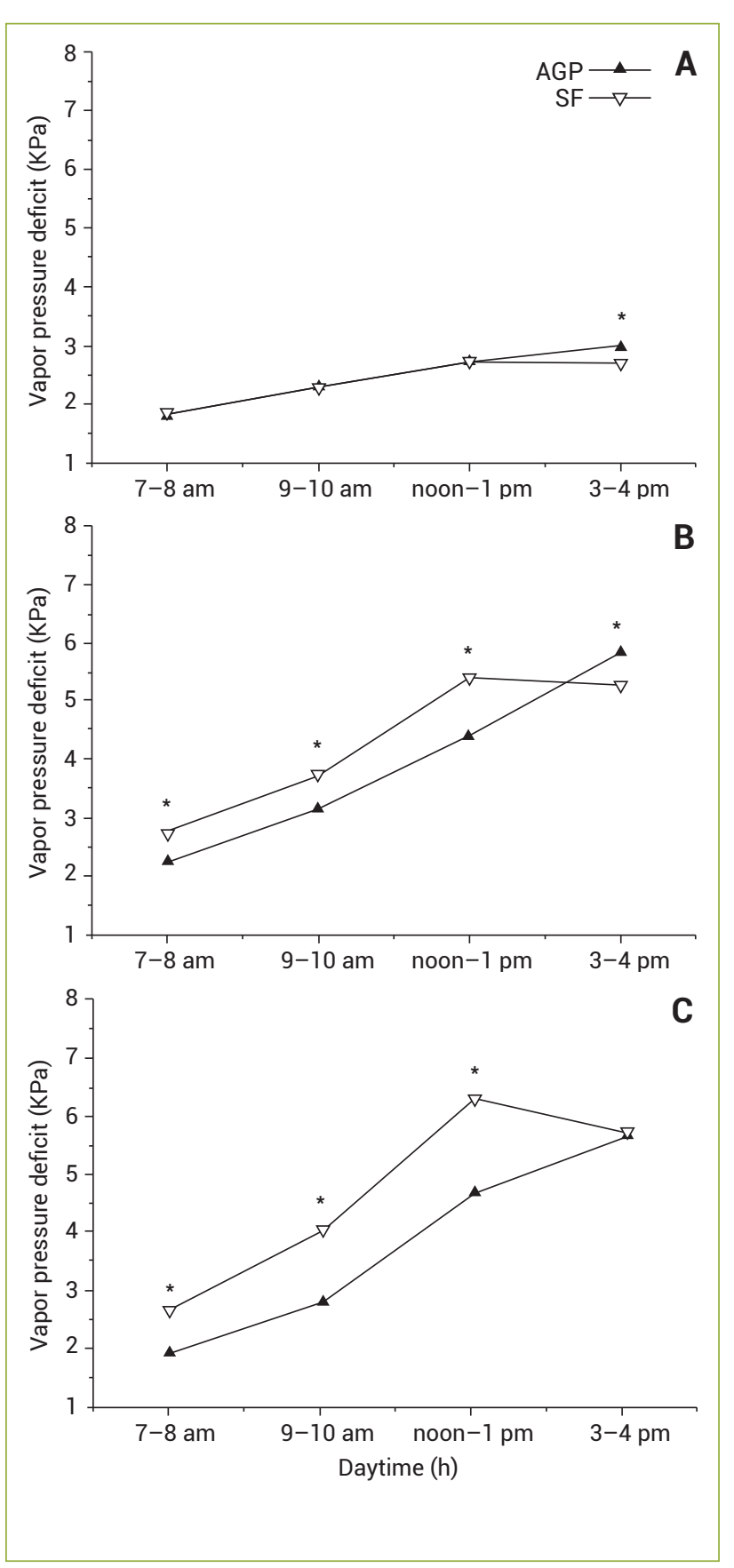

Figure 7. Leaf-to-air vapor pressure deficit in sun leaves of Cordia oncocalyx, in an agrosilvopastoral system (AGP) and a secondary forest (SF). (A) Wet season, average of values recorded between February and July ( $n=54)$; (B) Values recorded in August, 30 days after the final rainfall, during the dry season $(n=9)$; (C) Values recorded in September, 50 days after the final rainfall, during the dry season $(n=9)$. *indicates significant differences between land-use systems as determined by Student's $t$-test $(p<0.05)$.

contributed approximately $35 \%$ for the total dry biomass, whereas in SF this percentage was only $7.6 \%$, showing that fruit production is much higher in AGP.
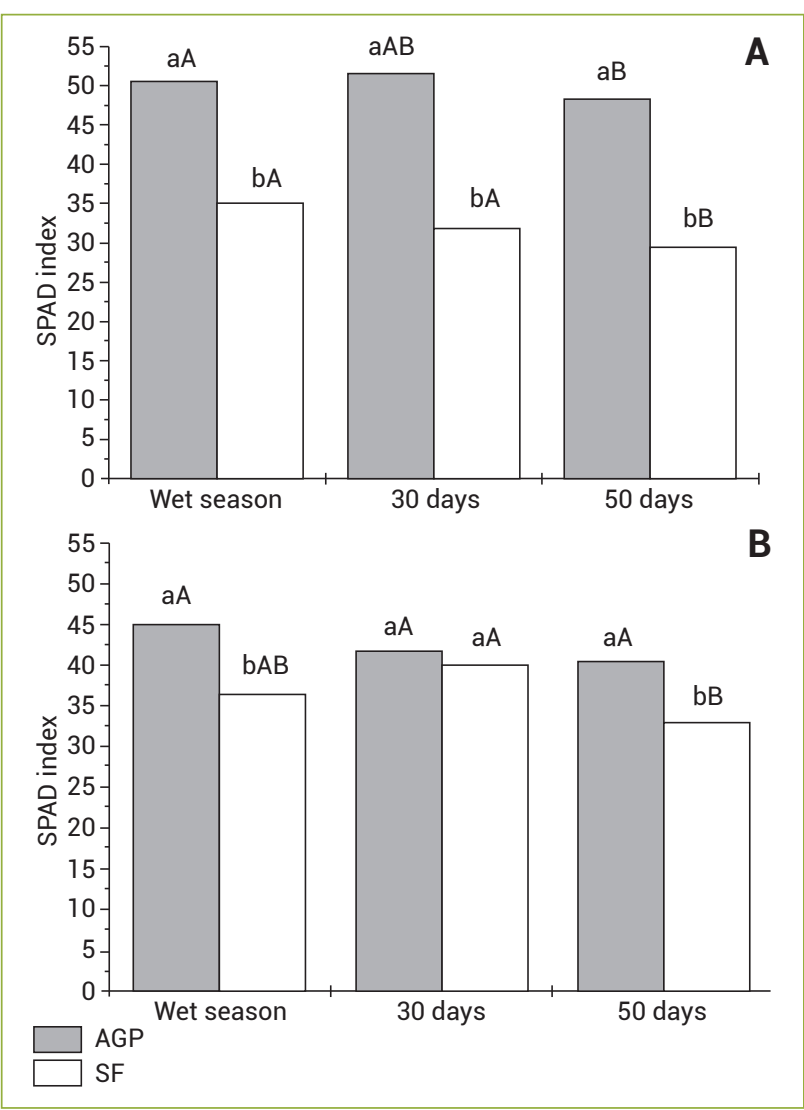

Figure 8. SPAD index in shaded (A) and sun (B) leaves of Cordia oncocalyx in an agrosilvopastoral system (AGP) and a secondary forest (SF). For the descriptions of evaluation times see the caption of Figure 5. Different lowercase letters indicate significant differences $(p<0.05)$ between land-use systems, and different uppercase letters indicate significant differences $(p<0.05)$ between seasons in the same land-use system, as determined by Tukey's test.

\section{DISCUSSION}

In the wet season, net photosynthesis was $32 \%$ higher in shaded leaves in AGP than in SF (Figure 5A), even though $\mathrm{PAR}, \mathrm{T}_{\text {leaf }}$ and $\mathrm{VPD}_{\text {leaf-to-air }}($ Table 1$)$, as well as $g_{s}$, were similar in both systems. Thirty days after the final rainfall, the beginning of leaf shedding enabled a more intense contact betweem solar radiation and shaded leaves in SF, increasing $A$ in this system even though $\mathrm{T}_{\text {leaf }}$ and $\mathrm{VPD}_{\text {leaf. }}$ to-air remained similar in both systems. Fifty days after the final rainfall, lower $V P D_{\text {leaf-to-air }}$ in shaded leaves in AGP led to greater stomatal opening, however, this did not translate into greater $A$. On the contrary, Egea et al. (2011) stated that $A$ increases with $g_{s}$, both of which are affected by the radiation intensity (Turner and Thomas 1998). Indeed, they both decrease with the reduced incidence of PAR (Rodrigues et al. 2011). Hence, although leaf humidity allowed stomatal opening, the reduced incidence of solar 
radiation affected the photochemical phase and reduced $A$ in shaded leaves of AGP.

Lower rates of $A, E$ and $g_{\mathrm{s}}$ were observed in shaded leaves in relation to sun leaves, as a result of the low levels of solar radiation received by the former (Figures $5 \mathrm{~A}-\mathrm{C}$ and $6 \mathrm{~A}-\mathrm{C}$, Table 1). Under clear skies, approximately four times less radiant flux density reaches the shaded leaves (Grant 1985). In addition, the high density of trees reduces the amount of PAR reaching shaded leaves, and has a direct influence on leaf gas exchange (Jensen et al. 2011). However, shaded leaves play the important role to compensate, by taking advantage of the weak radiation that reaches them, thus being able to ensure $\mathrm{CO}_{2}$ fixation in situations that would promote stomatal closure in sun leaves.

Net photosynthesis in sun leaves was similar in both systems in the wet season (Figure 6A). In that season, soil water content was not a limiting factor for the development of the plants, so $A$ was high. After the period of high water availability, the soil began to dry, and both the temperature and air vapor pressure deficit increased, creating conditions that are adverse to gas exchange (D’Ambrosio et al. 2006, Mahouachi 2009). Soil water can be retained longer in forests than in agroforests, due to the higher density of plants, lower surface runoff and reduced water loss by evaporation, since less solar radiation can reach the ground (Eastham et al. 1988, McDonald et al. 2002, Silva et al. 2011, Raz-Yaseef et al. 2012). It is therefore possible that in SF the higher density of trees and reduced transpiration rates during the dry season were the main responsible factors for the greater soil water content in this system 50 days after the final rainfall, compared to AGP.

In the dry season, $g_{s}, A, E$ and leaf water content were higher in the sun leaves in AGP, while water content in the soil was lower. Fifty days after the final rainfall, when soil water in AGP was lower than in SF (Figure 3), the higher leaf water content (Figure 4) allowed higher $E$ in the sun leaves in AGP (Figure 6C). High $\mathrm{VPD}_{\text {leaf-to-air }}$ in the sun leaves in SF partly explains the stomatal closure that occurred 50 days after the final rainfall, but not $30 \mathrm{~d}$, when leaves in AGP and SF had similar $\mathrm{VPD}_{\text {leafto-air }}$ Santos et al. (2013) observed greater $A$ in Jatropha curcas in a semi-humid forest than in a semiarid Caatinga area during the dry season, which they attributed to higher soil water content and lower $\mathrm{VPD}_{\text {leaf-to-air }}$. With increased $\mathrm{VPD}_{\text {leafto-air }} E$ increases, promoting a reduction in leaf water potential and leading to stomatal closure (Streck, 2003).

Gas exchange in C. oncocalyx was higher in the wet season for both areas, and lower at the start of the dry season for both shaded and sun leaves. This indicates that gas exchange was influenced by the seasons due to the drop in soil moisture at the beginning of the dry period. Similarly, Romero and Botía (2006) observed that Prunus dulcis showed $A$ ranging from 8 to $14 \mu \mathrm{mol} \mathrm{m}{ }^{-2} \mathrm{~s}^{-1}$ between 9:00 am and 5:00 pm during the wet season, whereas in the period of severe water stress, $A$ was high ( 8 to $10 \mu \mathrm{mol} \mathrm{m}^{-2} \mathrm{~s}^{-1}$ ) only between 1:00 pm and 3:00 pm. In addition, $g s$ and $A$ are influenced by water stress, while the relative water content in the leaf decreases (Gindaba et al. 2005). However, $A$ does not always depend on soil water content or on $\mathrm{VPD}_{\text {leafto-air }}$ (Streck 2003). This indicates that the different photosynthetic rates recorded in AGP and SF were also influenced by factors related to the plant itself. The techniques used in AGP alter the development patterns of the trees, given the lower density of plants in this system. Such low density can change rates of $A, E$ and WUE between individuals of the same species (Forrester et al. 2012).

In addition to the influence of weather conditions, which includegreaterVPD and airtemperature andlowersoilmoisture, all observed especially in the dry season, gas exchange is also affected by leaf maturity. Physiological processes in deciduous plants such as C. oncocalyx slow down at the start of the dry season, when leaf abscission begins. Thirty days after the final rainfall, at the start of the dry season, C. oncocalyx trees were shedding leaves differently in the two land-use systems. Uemura et al. (2005) and Muthuri et al. (2009) observed higher $A, E$, and WUE in young, mature leaves and a decrease in these variables with leaf senescence.

Nutrient content in the soil may also be responsible for the differences in physiology and yield. Plants growing in naturally or artificially fertile soils have a higher chlorophyll content, $A$ and production of above-ground biomass, as long as the radiation is not limiting, and this is regardless of plant density (Minotta and Pinzauti 1996, Groot and Saucier 2008). Similarly, because plants growing in nutrient-poor soils have lower chlorophyll

Table 2. Total fresh biomass per tree (TFM), percentage of dry biomass in subsamples (PDM), and total dry biomass per sample tree (TDM) of Cordia oncocalyx in a secondary forest (SF) and in an agrosilvopastoral system (AGP), in July

\begin{tabular}{lcccccc} 
& \multicolumn{2}{c}{ TFM $\left(\mathrm{kg} \mathrm{tree}^{-1}\right)$} & \multicolumn{2}{c}{ PDM (\%) } & \multicolumn{2}{c}{ TDM $\left(\mathrm{kg} \mathrm{tree}^{-1}\right)$} \\
\cline { 2 - 8 } & SF & AGP & SF & AGP & SF & AGP \\
Sun leaves & 8.63 & $23.07 * *$ & 42.16 & $45.77 *$ & 3.63 & $2.55^{* *}$ \\
Shaded leaves & 1.60 & $7.00 * *$ & 32.32 & $39.43^{* *}$ & 0.53 & $2.72 * *$ \\
Fruits & 0.54 & $9.33^{* *}$ & 63.87 & $79.28 * *$ & 0.34 & $7.33^{* *}$ \\
\hline Total & 10.77 & $39.40 * *$ & - & - & 4.50 & $20.60 * *$ \\
\hline
\end{tabular}

TFM and TDM $n=3 ;$ PDM $n=9$. The symbols indicate significant differences between land-use systems by Student's t-test: * $(p<0.05), * *(p<0.01)$. 
concentrations, their photosynthetic capacity and total biomass are reduced (Boussadia et al. 2010). Mendes (2013) reported higher levels of N, P and K in AGP than in SF, which shows that this improvement in soil fertility may be linked to the increased nutrient content in leaves and increased physiological processes of plants growing on that land-use system.

Leaves in SF exhibited a lower SPAD index (Figure 8), were more yellow in color than in AGP, and were more prone to falling from the tree. This is also relevant in terms of physiology, since chlorophyll is the pigment responsible for light absorption. Guerfel et al. (2009) observed that shaded plants exhibited higher chlorophyll content, which was attributed to the strategy developed by the plants to increase the amount of pigment necessary to absorb radiation. Even though the higher SPAD index in shaded leaves in AGP were associated with a lower incident PAR 30 and 50 days after the final rainfall, the effects on the chlorophyll obtained here cannot be explained directly by incident radiation, since PAR in sun leaves was higher in AGP, and also exhibited a higher SPAD index.

Despite the more beneficial physical environment promoted by $S F$, including greater soil moisture retention and reduced water loss by evaporation, the higher plant density in SF canlead to greater competition for water and nutrients, with negative consequences for leaf gas exchange and tree growth (Kilpeläinen et al. 2010). High intercession among the roots of neighboring trees, and the shade provided by a dense canopy, result in plants investing more energy in competition than in growth, as demonstrated by Gerhardt (1996). This suggests that given the lower tree density in AGP, C. oncocalyx plants may transfer more energy to increase their basal area and produce leaf and fruit biomass. Studies by Campanha et al. (2011) confirmed that many tree individuals in this agrosilvopastoral system were classified in groups of diameter

\section{REFERENCES}

Aguiar MI, Maia SMF, Oliveira TS, Mendonça ES, Araújo-Filho JA (2006) Perdas de solo, água e nutrientes em sistemas agroflorestais no município de Sobral, CE. Revista Ciência Agronômica 37:270-278.

Aguiar MI, Maia SMF, Xavier FAS, Mendonça ES, Araújo-Filho JA, Oliveira TS (2010) Sediment, nutrient and water losses by water erosion under agroforestry systems in the semi-arid region in northeastern Brazil. Agroforestry Systems 79:277-289.

Alfaia SS, Ribeiro GA, Nobre AD, Luizão RC, Luizão FJ (2004) Evaluation of soil fertility in smallholder agroforestry systems and pastures in western Amazonia. Agriculture, Ecosystems \& Environment 102:409-414.

Ayres M, Ayres-Júnior M, Ayres DL, Santos AA (2007) Bioestat Aplicações estatísticas nas áreas das ciências biomédicas. Ong Mamirauá, Belém, PA. larger than $0.18 \mathrm{~m}$. This was not the case in SF, where most individuals were in the $0-0.06 \mathrm{~m}$ diameter class.

We found that greater leaf dry biomass was associated with lower tree density in AGP. Subedi et al. (2012) demonstrated that the above-ground biomass decreases considerably when the density of trees increases from 700 to 4,000 individuals per hectare, with trees planted at lower density showing greater percentage of biomass as leaves. Hummel (2000) studied a different species of the genus Cordia [C. alliodora (Ruiz and Pav.) Oken] and observed that greater tree density resulted in stems with smaller diameters, as with C. oncocalyx in SF. This may be associated with greater competition, and the need for investment in plant height to improve light capture by the canopy (Strand et al. 2006).

Our findings suggest that $C$. oncocalyx plants in AGP may be more resistant to drought compared to the plants in SF. Indeed, they maintain greener leaves with higher relative content of chlorophyll. Trees also maintained higher rates of $E, g_{s}$, and $A$ throughout the day in sun leaves, with higher WUE and leaf water content, $50 \mathrm{~d}$ after the final rainfall in the dry season, when the gravimetric soil water content was low. This may be explained by the impact of agroforestry management techniques, including low tree density and differences in nutrient availability and in other soil properties.

\section{ACKNOWLEDGEMENTS}

The authors would like to thank Embrapa Goats and Sheep for allowing the field work for this study. We are also grateful to the Coordination for Enhancement of Higher Eduation Personnel (CAPES) and the National Council for Scientific and Technological Development (CNPq) for their financial support.

Boussadia O, Steppe K, Zgallai El Hadj SB, Braham M, Lemeur R, Van LabekeMC (2010) Effects of nitrogen deficiency on leaf photosynthesis, carbohydrate status and biomass production in two olive cultivars 'Meski' and 'Koroneiki'. Scientia Horticulturae 123:336-342.

Campanha MM, Aguiar MI, Maia SM, Oliveira TS, Mendonça ES, Araújo-Filho JA (2008) Perdas de solo, água e nutrientes pela erosão hídrica em diferentes sistemas de manejo agroflorestal no semiárido cearense. Embrapa, Sobral, CE, Brasil. Circular Técnica, 37.

Campanha MM, Nogueira RS, Oliveira TS, Teixeira AS, Romero RE (2009) Teores e estoque de carbono no solo de sistemas agroflorestais e tradicionais no semiárido brasileiro. Embrapa, Sobral. Circular Técnica, 42.

Campanha MM, Araújo FS, Menezes MO, Silva VM, Medeiros HR(2011) Structure of plantcommunity of shrubs and trees in agrosilvopasture system, in Sobral - CE. Revista Caatinga 24:94-101. 
Carvalho PER (2008) Pau-branco-do-sertão (Auxemma oncocalyx). Embrapa Florestas, Colombo-PR. Circular Técnica, 153.

D'Ambrosio N, Arena C, Santo AV (2006) Temperature response of photosynthesis, excitation energy dissipation and alternative electron sinks to carbon assimilation in Beta vulgaris $\mathrm{L}$. Environmental and Experimental Botany 55:248-257.

Eastham J, Rose CW, Cameron DM, Rance SJ, Talsma T (1988) The effect of tree spacing on evaporation from an agroforestry experiment. Agricultural and Forest Meteorology 42:355-368.

Egea G, Verhoef A, Vidale PL (2011) Towards an improved and more flexible representation of water stress in coupled photosynthesis - stomatal conductance models. Agricultural and Forest Meteorology 151:1370-1384

Empresa Brasileira de Pesquisa Agropecuária - EMBRAPA (1997) Manual de métodos de análise de solo, segunda ed. Ministério da Agricultura, Rio de Janeiro, Brasil.

Forrester DI, Collopy JJ, Beadle CL, Warren CR, Baker TG (2012) Effect of thinning, pruning and nitrogen fertiliser application on transpiration, photosynthesis and water-use efficiency in a young Eucalyptus nitens plantation. Forest Ecology and Management 266:286-300.

Gerhardt K (1996) Effects of root competition and canopy openness on survival and growth of tree seedlings in a tropical seasonal dry forest. Forest Ecology and Management 82:33-48.

Gindaba J, Rozanov A, Negash L (2005) Photosynthetic gas exchange, growth and biomass allocation of two Eucalyptus and three indigenous tree species of Ethiopia under moisture deficit. Forest Ecology and Management 205:127-138.

Grant RH (1985) The influence of the sky radiance distribution on the flux density in the shadow of a tree crown. Agricultural and Forest Meteorology 35:59-70.

Groot A, Saucier JP (2008) Volume increment efficiency of Picea mariana in northern Ontario, Canada. Forest Ecology and Management 255:1647-1653.

Guerfel M, Obaccouri O, Boujnah D, Chai Bi W, Zarrouk M (2009) Impacts of water stress on gas exchange, water relations, chlorophyll content and leaf structure in the two main Tunisian olive (Olea europaea L.) cultivars. Scientia Horticulturae 19:257-263.

Hummel S (2000) Height, diameter and crown dimensions of Cordia alliodora associated with tree density. Forest Ecology and Management 127:31-40.

Instituto Brasileiro de Geografia e Estatística - IBGE (2006) Censo Agropecuário. IBGE, Rio de Janeiro, Brasil.

Jensen AM, Löf M, Gardiner ES (2011) Effects of above- and below-ground competition from shrubs on photosynthesis, transpiration and growth in Quercus robur L. seedlings. Environmental and Experimental Botany 71:367-375.

Kilpeläinen A, Routa J, Peltola P, Gerendiain AZ, Pulkkinen $P$, Kellomäki S (2010) Effects of genetic entry and competition on above ground biomass production of Norway spruce grown in southern Finland. Forest Ecology and Management 259:2327-2332.
Lott JE, Howard SB, Ong CK, Black CR (2000) Long-term productivity of a Grevillea robusta-based overstorey agroforestry system in semi-arid Kenya: I. Tree growth. Forest Ecology and Management 139:175-186.

Maia SMF, Xavier FAS, Oliveira TS, Mendonça ES, Araújo-Filho JA (2008) Frações de nitrogênio em Luvissolo sob sistemas agroflorestais e convencional no semi-árido cearense. Revista Brasileira de Ciência do Solo 32:381-392.

Mahouachi J (2009) Changes in nutrient concentrations and leaf gas exchange parameters in banana plantlets under gradual soil moisture depletion. Scientia Horticulturae 120:460-466.

McDonald MA, Healey JR, Stevens PA (2002) The effects of secondary forest clearance and subsequent land-use on erosion losses and soil properties in the Blue Mountains of Jamaica. Agriculture, Ecosystems \& Environment 92:1-19.

Mendes MMS (2013) Ecofisiologia de plantas nativas e cultivadas e parâmetros físicos e químicos do ambiente em sistemas agroflorestais no semiárido cearense. Fortaleza, Universidade Federal do Ceará. PhD thesis.

Menezes RSC, Salcedo IH, Elliott ET (2002) Microclimate and nutrient dynamics in a silvopastoral system of semiarid northeastern Brazil. Agroforestry Systems 56:27-38.

Microcal Software INC. (1997) Data analysis and technical graphics software. Origin Professional version 6.0. Northampton, MA.

Minotta G, Pinzauti S (1996) Effects of light and soil fertility on growth, leaf chlorophyll content and nutrient use efficiency of beech (Fagus sylvatica L.) seedlings. Forest Ecology and Management 86:61-71.

Moço MKS, Gama-Rodrigues EF, Gama-Rodrigues AC, Machado RCR, Baligar VC (2010) Relationships between invertebrate communities, litter quality and soil attributes under different cacao agroforestry systems in the south of Bahia, Brazil. Applied Soil Ecology 46:347-354.

Muthuri CW, Ong CK, Craigon J, Mati BM, Ngumi VW, Black CR (2009) Gas exchange and water use efficiency of trees and maize in agroforestry systems in semi-arid Kenya. Agriculture, Ecosystems \& Environment 129:497-507.

Raz-Yaseef N, Yakir D, Schiller G, Cohen S (2012) Dynamics of evapotranspiration partitioning in a semi-arid forest as affected by temporal rainfall patterns. Agricultural and Forest Meteorology $157: 77-85$

Rodrigues BM, Arcoverde GB, Antonino AC, Santos MG (2011) Water relations in physic nut according to climatic seasonality, in semiarid regions. Pesquisa Agropecuária Brasileira 46:1112-1115.

Romero P, Botía P (2006) Daily and seasonal patterns of leaf water relations and gas exchange of regulated deficit-irrigated almond trees under semiarid conditions. Environmental and Experimental Botany 56:158-173.

Santos CM, Veríssimo V, Wanderley-Filho HCL, Ferreira VM, Cavalcante PGS, Rolim EV, Endres L (2013) Seasonal variations of photosynthesis, gas exchange, quantum efficiency of photosystem II and biochemical responses of Jatropha curcas L. grown in semi-humid and semi-arid areas subject to water stress. Industrial Crops and Products 41, 203-213. 
Silva GL, Lima HV, Campanha MM, Gilkes RJ, Oliveira TS (2011) Soil physical quality of Luvisols under agroforestry, natural vegetation and conventional crop management systems in the Brazilian semi-arid region. Geoderma 167-168:61-70.

Singh G, Mutha S, Bala N (2007) Effect of tree density on productivity of a Prosopis cineraria agroforestry system in North Western India. Journal of Arid Environments 70:152-163.

Souza HN, Goede RGM, Brussaard L, Cardoso IM, Duarte EMG, Fernandes RBA, Gomes LC, Pulleman MM (2012) Protective shade, tree diversity and soil properties in coffee agroforestry systems in the Atlantic Rainforest biome. Agriculture, Ecosystems \& Environment 146:179-196.

Strand M, Löfvenius MO, Bergsten U, Lundmark T, Rosvall O (2006) Height growth of planted conifer seedlings in relation to solar radiation and position in Scots pine shelterwood. Forest Ecology and Management 224:258-265.

Streck N (2003) Stomatal response to water vapor pressure deficit: an unsolved question. Revista Brasileira de Agrociência 9:317-322.
Subedi S, Kane M, Zhao D, Borders B, Greene D (2012) Cultural intensity and planting density effects on aboveground biomass of 12-year-old loblolly pine trees in the Upper Coastal Plain and Piedmont of the southeastern United States. Forest Ecology and Management 267:157-162.

Turner DW, Thomas DS (1998) Measurements of plant and soil water status and their association with leaf gas exchange in banana (Musa spp.): a laticiferous plant. Scientia Horticulturae 77:177-193.

Uemura A, Ishida A, Matsumoto $Y$ (2005) Simulated seasonal changes of $\mathrm{CO}_{2}$ and $\mathrm{H}_{2} \mathrm{O}$ exchange at the top canopies of two Fagus trees in a winter-deciduous forest, Japan. Forest Ecology and Management 212:230-242.

Will RE, Barron GA, Burkes EC, Shiver B, Teskey RO (2001) Relationship between intercepted radiation, net photosynthesis, respiration, and rate of stem volume growth of Pinus taeda and Pinus elliottii stands of different densities. Forest Ecology and Management 154:155-163.

Woodward Fl, Lomas MR, Kelly CK (2004) Global climate and the distribution of plant biomes. Philosophical Transactions of the Royal Society B: Biological Sciences 359:1465-1476. 